\title{
Enhancing Students' Motivation using Facebook and SMS with Google Spreadsheets Support: A Comparative Study
}

\author{
Chaiprasurt, $\mathbf{C .}^{1}$ \\ ${ }^{1}$ Department of Computer Science, Faculty of Information Technology, Thepsatri Rajabhat \\ University, Lop Buri, Thailand
}

Corresponding email: cpuija@gmail.com

\begin{abstract}
To the widespread use of wireless technologies, increased portable mobile devices and communication contributes to stimulate and encourage group sharing among instructors and students in the learning environments. Apt applications to boost old face-to-face teaching were examined, which are SMS, Facebook and Google Spreadsheets. A research was used to actual analyze the influence on their interests. It took place over a period of 14 weeks, and the sample consisted of 42 students in Information Technology for Social Network class. Three groups were involved, control (only supported by Google Spreadsheets), the first group (supported by Google Spreadsheets and SMS), and the second group (supported by Google Spreadsheets and Facebook). The effect of the applications, the results of subjective (attention, relevance, confidence, satisfaction and social ability) and objective assessment (engagement and academic performance) were compared among the three groups, and by using Google Spreadsheets with SMS, and with Facebook were effective in improving their motivation. Notable difference in overall was, students preferred Google spreadsheets with SMS, where it enhanced their motivation when merge into learning.
\end{abstract}

Keywords: Facebook; Google Spreadsheets; Motivation; SMS

DOI: http://dx.doi.org/10.20961/ijpte.v3i1.25370 


\section{INTRODUCTION}

Motivation plays a major role in learning, where effective interventions have been carried out which may uphold their interests. The motivation of the learner is determined by the quality and potent regarding any form of learning (Cocea and Weibelzaha, 2006). Approaches on motivational design in learning are mostly based on Keller's ARCS model, which are attention, relevance, confident and satisfaction (e.g. Keller, 2008).

Mobile phone is all over and aspect of learning via mobile phone is still its infancy, whereas through research it can be used as an educational tool and it can support their learning. Through the learning has become more available by creating tools technology such as Bluetooth, wireless, 4G, SMS, MMS, WAP, and mobile phones are becoming pervasive information and communication technology (ICT) tools in the learning environment. It has become more available in the pre-existing learning domains and supporting team work.

Team work support information exchanges with instructors and peers, to utilize the mobility, communication features together with the devices such as: Google Spreadsheets, Facebook and SMS, can develop a learning environment inspired by the teamwork principle (Patten et al., 2006). Google Spreadsheets are explored for promoting teamwork and have the potential to enhance instructional methods. Students working from multiple computers share a single spreadsheet, using each other's work to guide their understanding of complex calculations, while creating opportunities for timely instructor-and interaction. Facebook is the most popular platform for online social networking in Thailand. In this study, Facebook group and Messenger was used as a learning management system (LMS) for sharing resources, putting up announcements, and conducting online discussions. SMS, text-based services permits up to a maximum of 160 characters to be sent to other users. It is suitable for 'reminders' allowing them to take part in collective learning, and offering education service.

A study by Chaiprasurt and Esichaikul (2013) was concluded on the table 1: that development of mobile communication tools to enhance motivation in learning is guided by a combination of Keller's ARCS motivation model and collaboration. The devices were developed for individual use, their potential to benefit them is enormous. They could play an important part in increasing flexibility to deliver more on personalized and student-centred activities. To achieve this, in the learning process, we need to enhance their interests and by doing so, identifying the aspect to use and bond in the learning process.

\section{MOBILE COMMUNICATION TOOLS}

This compares traditional face-to-face teaching among students, implemented on a smart phone, includes sms, facebook and google spreadsheets, which were used to communicate with them. The arcs and collaboration factors discussed earlier represent the main dimensions in learning found that they should suit their needs and whether students can access them timely (chaiprasurt, 2013). 
TABLE 1.A Mobile Communication Tools Framework

\begin{tabular}{|c|c|}
\hline Motivational factors & Mobile communication tools \\
\hline $\begin{array}{l}\text { Attention: arousing and sustaining learners' } \\
\text { curiosity and interest in the instruction or } \\
\text { learning activities }\end{array}$ & $\begin{array}{l}\text { - SMS (asking questions and receiving } \\
\text { course notifications and } \\
\text { announcements) } \\
\text { - Mobile RSS feeds (information } \\
\text { related to the topic being taught, } \\
\text { forums, news) }\end{array}$ \\
\hline $\begin{array}{l}\text { Relevance: relating the instruction to learners' } \\
\text { needs, interests, and motives }\end{array}$ & $\begin{array}{l}\text { - SMS (URL-related instruction and } \\
\text { course information) }\end{array}$ \\
\hline $\begin{array}{l}\text { Confidence: learners' expectations of a } \\
\text { successful learning experience }\end{array}$ & $\begin{array}{l}\text { - } \text { Assignment feedback tool } \\
\text { - } \text { Grade-book tool } \\
\text { - } \\
\text { - } \\
\text { - Sttendance reporting tool } \\
\text { (reinforcing feedback) }\end{array}$ \\
\hline $\begin{array}{l}\text { Satisfaction: learners' sense of achievement } \\
\text { regarding learning activities or experiences }\end{array}$ & - $\quad$ SMS (grading results) \\
\hline $\begin{array}{l}\text { Collaboration: working together with other } \\
\text { learners or groups to accomplish shared goals }\end{array}$ & $\begin{array}{l}\text { - Mobile instant messaging (MIM) } \\
\text { - Mobile blogging } \\
\text { - Mobile polls and votes }\end{array}$ \\
\hline
\end{tabular}

\section{Analysis of Mobile Communication Tools}

This step aims to analyze tools and technologies to enhance interaction in the traditional classroom setting. The survey consisted of 42 undergraduate who enrolled for IT in Social Network Faculty of Information Technology. The most favorite tool to use as a supplement of their learning was SMS (37.2\%), Facebook (32.6\%) and Google Spreadsheets $(25.5 \%)$ respectively. The survey also revealed that they want to know their grading results, course notifications and announcements, via their mobile phone accounted for $98 \%, 97.5 \%, 97.25 \%$ and $96.5 \%$, respectively.

By the analysis above the tools designed for supporting classroom learning can be accomplished by using mobile devices guided by a mobile communication tools. The ARCS and collaboration factors represent the main dimensions of their personal interests in online learning. These factors are discussed below (See Table 2).

\section{Design of Attention in Mobile Communication}

Tools Strategies to gain and sustain their interests include: capturing their interest, stimulating curiosity and maintaining attention (variation) (Keller, 1987). Based on these strategies, Facebook was designed to support receiving course notifications, announcements and information related to topic, whereas SMS providing course notifications and announcements only. 
- Course notification and announcements

They receive course notification, such as deadlines for assignment submissions. It is useful to sustain them and gain attention in learning.

- Information related to topic being taught and news

It enables them to view and manage all posts in Facebook. This allows them to edit and add the selection of turn on or off notifications and commenting. This tool is also employed to retain and invigorate their attention which can account for frequent, unexpected and challenging communication.

TABLE2. Applying mobile communication tools framework with existing technologies for enhancing

\begin{tabular}{|c|c|c|c|}
\hline Motivational factors & SMS & Facebook & $\begin{array}{c}\text { Google } \\
\text { Spreadsheets }\end{array}$ \\
\hline \multirow{2}{*}{$\begin{array}{l}\text { Attention: arouse and } \\
\text { sustain learners' curiosity } \\
\text { and interest in the } \\
\text { instruction or learning } \\
\text { activities. }\end{array}$} & $\begin{array}{l}\text { SMS (receiving } \\
\text { course notifications } \\
\text { and announcements) }\end{array}$ & $\begin{array}{l}\text { Facebook Group } \\
\text { (course notifications } \\
\text { and announcements) }\end{array}$ & - \\
\hline & - & $\begin{array}{l}\text { Facebook Group } \\
\text { (information related to } \\
\text { topic being taught, } \\
\text { news) }\end{array}$ & - \\
\hline $\begin{array}{l}\text { Relevance: relation of the } \\
\text { instruction to the learner's } \\
\text { need, interest and motive. }\end{array}$ & $\begin{array}{l}\text { SMS (URL related } \\
\text { instruction \& course } \\
\text { information) }\end{array}$ & $\begin{array}{l}\text { Facebook Group (URL } \\
\text { related instruction \& } \\
\text { course information) }\end{array}$ & - \\
\hline \multirow{2}{*}{$\begin{array}{l}\text { Confidence: learner's } \\
\text { expectation for successful } \\
\text { learning experience }\end{array}$} & $\begin{array}{l}\text { SMS (reinforcing } \\
\text { feedback) }\end{array}$ & $\begin{array}{l}\text { Facebook Messenger } \\
\text { (assignment feedback) }\end{array}$ & Grade-book report \\
\hline & - & - & Attendance report \\
\hline $\begin{array}{l}\text { Satisfaction: learner's } \\
\text { sense of achievement } \\
\text { regarding the learning } \\
\text { activities or experiences. }\end{array}$ & SMS (grading results) & $\begin{array}{l}\text { Facebook Messenger } \\
\text { (grading results) }\end{array}$ & - \\
\hline \multirow{2}{*}{$\begin{array}{l}\text { Collaboration: working } \\
\text { together with another } \\
\text { learner or group to } \\
\text { accomplish shared goals. }\end{array}$} & - & $\begin{array}{l}\text { Facebook polls and } \\
\text { votes }\end{array}$ & - \\
\hline & - & $\begin{array}{l}\text { Facebook Messenger } \\
\text { (instant messaging) }\end{array}$ & - \\
\hline
\end{tabular}

\section{Design of Relevance in Mobile Communication}

Tools Relevance involves catering to their need and ensure significant personal requirements are being met, and to link what they need to know with the opportunities offered (Keller, 1987). By the instruction to their experiences linking to their interests and furthering personal understanding and competence, SMS and Facebook were designed to support this factor comprise URL-related instruction and course information. 
- URL-related instruction and course information

This where instructors help students to understand their poor scores and submit assignments, and get their detailed feedback.

\section{Design of Confidence in Mobile Communication Tools}

Confidence is positive expectations for success and fear of failure. It is important to help them believe that they will succeed and gain self-confidence. Instructors provide fosters with positive expectation for success (learning requirements), belief in competence based upon their abilities and efforts. Google Spreadsheets used comprise of: attendance report and grade-book. SMS and Facebook messenger are used for reinforcing and assignment feedback. The details of each tool are:

- Attendance report

Their attendance record is the most significant factor influencing his/her academic success. By emphasizing the attendance, it is important to let them know they are responsible for their success through their personal abilities.

- Grade-book

The grade-book is an individual performance. They are more comfortable accessing their grades through Google Spreadsheets. The grading, measuring and notification of performance will help them believe in their potential success.

- Reinforcing feedback

Reinforcing differs from general information of praise, recognition, encouragement, and affirmation. This tool allows instructors to deliver bulk SMS messages to tell students. Providing adequate, encouraging feedback helps them believe in themselves and their ability.

- Assignment feedback

It provides personal and directly related information to a particular piece of students' work more convenient way to access feedback. With the feedback they can maintain or improve where they can, which can raise their self-confidence. Design of Satisfaction in Mobile Communication Tools Satisfaction serves to increase their motivation, which can be extrinsic or intrinsic, by building positive feelings). It makes them feel satisfied with their accomplishments, which is closely related to confidence (Keller, 2010). Using these strategies, are designed to support grading result.

\section{- Grading result}

With the grading results, they can be encouraged to continue their good work and improve. Announcement of grades is important for those who require more assistance and need improvement. Using SMS and Facebook messenger are a great way to immediately communicate necessary information to them. This tool appears to support and encourage them. 


\section{Design of Collaboration in Mobile Communication Tools}

Collaborative learning through social interaction, are extensively acknowledged as they are more motivated to learn (Miyake, 2007; Dillenbourg, 1999). Environments mention in a context where the computer facilitates social interaction among participants for developing and sharing knowledge. They allow collaboration, regardless of physical location. They provide multimedia, network, and integrated context-aware capabilities that are able to capture any detail about location and time. They are able to connect together and access more resources. Facebook Messenger provides communication and collaboration among students.

- Instant Messaging (IM)

Peer discussions can improve the participants' sense of community within their specific group. Instant messaging (IM) is a natural medium for the online community by helping to foster a greater sense of online cooperation. Facebook Messenger gives students the ability to instantly communicate, share information, and improve team work. It is very convenient to be able to stay connected.

\section{- Facebook polls and votes}

The instructor makes a poll on Facebook and they respond to the survey using their mobile devices, which is an increasingly important way of reaching them. Polling improves the sharing of opinions, ideas, and exchange of information, whereas improves collaborative power to learning, which inspire and motivate to engage more learning.

\section{METHOD}

This paper aimed to promote a new approach which will motivate them by using technologies or applications from mobile devices. By students applications, which included SMS, Facebook and Google Spreadsheets, were used to communicate with students. Course Motivation Surveys were distributed to students near the end of the course by hand.

\section{Research Methodology}

This study was designed to compare learning motivation among students in a course supported by Google Spreadsheets only, those taught using SMS with Spreadsheets and using Facebook with Spreadsheets (see Figure 1). An experimental comparison of three groups was carried out in the Faculty of Information Technology at a university in Thailand. The sample consisted of 42 undergraduate students enrolled in a course called IT for Social Network Learning. These participants were assigned to control group $(n=14)$, the first ( $=13)$ and the second $(n=15)$ groups on the basis of their demographic profile in order to ensure homogeneity, thus reducing bias. All students learned with the same content and course materials. They were formatively assessed through their participation in class, individual and group assignments, and summative assessments including assignment grades, midterm and final exams.

In the three groups data were collected on the basis of their actions. This measured on objective assessment including their academic performance, 
attendance and engagement. They were also asked to complete the Course Motivation Survey for subjective assessment, which was designed to identify motivation in terms of attention, relevance, confidence, satisfaction and social ability. The survey had 45 items and each item was mapped according to the respondent's perception of the construct for the given ARCS-Social ability component. All measurement items were developed in response to the literature. Evidence to support the validity of the content was obtained via a panel of simulation experts, which yielded validity index of .92 . The reliability of the instrument was also analysed, which accounted for 0.96 (Chaiprasurt, 2013).

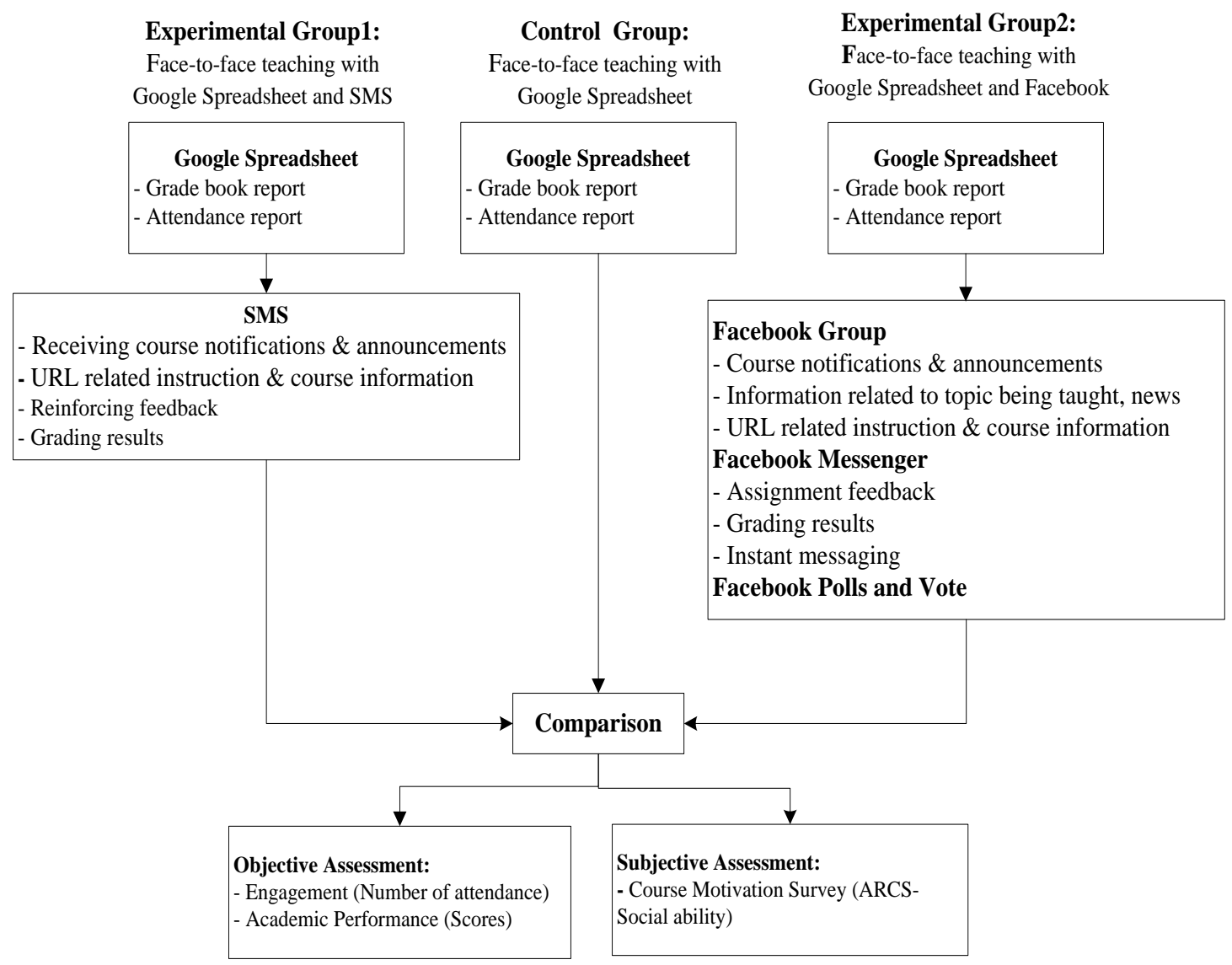

FIGURE 1. Experimental Procedure

\section{RESULTS}

To evaluate the impact, the analysis revealed no difference in the demographic makeup of the treatment and control groups by pre-tests scores, computer and mobile application skills and experiences.

\section{Objective}

\section{Assessment Engagement}

The numbers of students' attendance to the class were counted and compared where they were greater than those of the control group (see Table 3). 
TABLE 3. Student attendance and Chi-Square result

\begin{tabular}{cccccc}
\hline $\begin{array}{c}\text { The number of } \\
\text { attendance }\end{array}$ & $\begin{array}{c}\text { Con. } \\
(\boldsymbol{n}=\mathbf{1 4})\end{array}$ & $\begin{array}{c}\text { Exp.1 } \\
(\boldsymbol{n}=\mathbf{1 3})\end{array}$ & $\begin{array}{c}\text { Exp.2 } \\
(\boldsymbol{n}=\mathbf{1 5})\end{array}$ & $\begin{array}{c}\text { Chi- } \\
\text { square }\end{array}$ & $\boldsymbol{P}$-value \\
\hline Less than 5 & $1(7.1)$ & - & - & & \\
$5-6$ & $1(7.1)$ & - & $1(6.7)$ & & \\
$7-8$ & - & $2(15.4)$ & - & & \\
$9-10$ & $3(21.4)$ & $1(7.7)$ & $2(13.3)$ & & \\
$11-12$ & $2(14.3)$ & $3(23.1)$ & $4(26.7)$ & & \\
$13-14$ & $7(50.0)$ & $7(53.8)$ & $8(53.3)$ & & \\
\hline
\end{tabular}

\section{Academic performance}

Academic performance, scores on assignments and tests were evaluated. They were asked to submit assignments weekly, and their average scores were evaluated, whereas the average scores on both tests were evaluated during treatment and post-treatment, respectively. Those in the experimental groups accomplished better learning scores with the proposed tools (see Table 4).

TABLE 4. Descriptive statistics on assignments, midterm and final exams

\begin{tabular}{lcccccc}
\hline \multirow{2}{*}{ Scores } & \multicolumn{2}{c}{ Con. $(\mathbf{n = 1 4})$} & \multicolumn{2}{c}{ Exp.1(n=13) } & \multicolumn{2}{c}{ Exp.2(n=15) } \\
& Mean & SD & Mean & SD & Mean & SD \\
\hline Assignments (100\%) & 76.30 & 9.47 & 78.27 & 7.76 & 76.75 & 11.41 \\
Midterm (100\%) & 51.21 & 20.01 & 52.58 & 12.03 & 52.90 & 9.92 \\
Final (100\%) & 60.21 & 12.71 & 64.92 & 12.86 & 60.30 & 11.50 \\
Total(100\%) & 62.57 & 12.66 & 65.26 & 9.13 & 63.32 & 8.72
\end{tabular}

Subjective Assessment

\section{ARCS-Social ability}

A one-way MANOVA was performed to determine whether there are any differences in motivation between students in the course among three groups on the five dependent measures below. Significant main effects were found for the use of the proposed tools, Wilks' $\lambda=.54, \mathrm{~F}(10,42)=2.55, \mathrm{p}=.011, \eta 2=0.267$. Table 5 presents the mean values and the results of the pairwise comparison ( $t-$ test) performed on the three groups obtained from the Course Motivation Survey.

A significant mean difference between students in the control (only Google Spreadsheets) and the first experimental group (Google Spreadsheets with SMS), attention $(\mathrm{p}=.0002)$, confidence $(\mathrm{p}=.029)$, and the overall measure of motivation $(\mathrm{p}=.019)$. The table also shows a significant mean difference between students in the control and the second experimental group (Google Spreadsheets with Facebook) in attention factor $(\mathrm{p}=0.012)$. The means for overall motivation measures of students in the experimental groups were higher than those in the 
control group. The attention variable shows the biggest difference in means between the experimental and control groups.

TABLE 5. Comparison of means of subjective measures by t-test

\begin{tabular}{|c|c|c|c|c|c|}
\hline $\begin{array}{l}\text { Dependent } \\
\text { variable }\end{array}$ & (I)Mobile Technologies & (J)Mobile Technologies & $\begin{array}{l}\text { Mean } \\
\text { Difference(I- } \\
\text { J) }\end{array}$ & $\begin{array}{l}\text { Std. } \\
\text { Error }\end{array}$ & $\mathbf{p}$ \\
\hline \multirow{3}{*}{ Attention } & \multirow{2}{*}{ Google Spreadsheets } & Google Spreadsheets+SMS & -0.442 & 0.134 & $0.002 *$ \\
\hline & & Google Spreadsheets+FB & -0.339 & 0.129 & $0.012 *$ \\
\hline & $\begin{array}{l}\text { Google } \\
\text { Spreadsheets+SMS }\end{array}$ & Google Spreadsheets+FB & 0.104 & 0.132 & 0.435 \\
\hline \multirow{3}{*}{ Relevance } & \multirow{2}{*}{ Google Spreadsheets } & Google Spreadsheets+SMS & -0.041 & 0.156 & 0.795 \\
\hline & & Google Spreadsheets+FB & -0.069 & 0.150 & 0.650 \\
\hline & $\begin{array}{l}\text { Google } \\
\text { Spreadsheets+SMS }\end{array}$ & Google Spreadsheets+FB & -0.028 & 0.153 & 0.856 \\
\hline \multirow{3}{*}{ Confidence } & \multirow{2}{*}{ Google Spreadsheets } & Google Spreadsheets+SMS & -0.419 & 0.184 & 0.029* \\
\hline & & Google Spreadsheets+FB & -0.140 & 0.178 & 0.435 \\
\hline & $\begin{array}{l}\text { Google } \\
\text { Spreadsheets+SMS }\end{array}$ & Google Spreadsheets+FB & 0.279 & 0.181 & 0.132 \\
\hline \multirow{3}{*}{ Satisfaction } & \multirow{2}{*}{ Google Spreadsheets } & Google Spreadsheets+SMS & -0.358 & 0.180 & 0.054 \\
\hline & & Google Spreadsheets+FB & -0.300 & 0.174 & 0.091 \\
\hline & $\begin{array}{l}\text { Google } \\
\text { Spreadsheets+SMS }\end{array}$ & Google Spreadsheets+FB & 0.058 & 0.177 & 0.747 \\
\hline \multirow{3}{*}{ Collaboration } & \multirow{2}{*}{ Google Spreadsheets } & Google Spreadsheets+SMS & -0.360 & 0.189 & 0.056 \\
\hline & & Google Spreadsheets+FB & -0.277 & 0.182 & 0.137 \\
\hline & $\begin{array}{l}\text { Google } \\
\text { Spreadsheets+SMS }\end{array}$ & Google Spreadsheets+FB & 0.113 & 0.186 & 0.546 \\
\hline \multirow{3}{*}{ Overall } & \multirow{2}{*}{ Google Spreadsheets } & Google Spreadsheets+SMS & -0.330 & 0.135 & $0.019 *$ \\
\hline & & Google Spreadsheets+FB & -0.225 & 0.130 & 0.092 \\
\hline & $\begin{array}{l}\text { Google } \\
\text { Spreadsheets+SMS }\end{array}$ & Google Spreadsheets+FB & 0.105 & 0.133 & 0.434 \\
\hline
\end{tabular}




\section{CONCLUSION AND DISCUSSION}

The study compares motivation among three groups being taught through a traditional classroom using Google Spreadsheets only, Spreadsheets with SMS, and Spreadsheets with Facebook support. The results revealed no difference in the demographic makeup among the three groups. The findings of enhancing motivation are based on objective assessment on recorded actions, and subjective assessment on their preferences and opinions. The findings confirm that the proposed tools can be used suitably to support learning process, and enhance motivation. Using Google Spreadsheets by allowing students to check their grades, assignments, test scores, and attendance through the website is pull technology. Pull and push technology should be used together such as sending SMS for reinforcing feedback and reminding course notifications. However, the cost of sending SMS should be considered. The achievement in learning between students receiving SMS from teachers and students who contacted teachers on Facebook were not significantly different. Many studies also conclude that Facebook can be used as an educational communication and interaction tool to assist students in achieving higher engagement, better grades, and greater satisfaction with learning experience, because it is used in everyday life (e.g. Jenny, et al., 2013; Madge, et al., 2009; Mazer, et al., 2007).

\section{FUTURE RESEARCH CONSIDERATIONS}

There are three main areas of future work that are significant to leverage improvement: using social media with learning, investigation of the tools on outcomes, and communication style and message quality. Firstly, the future research area should concern the ways in which students can use other social media such as Line, Twitter and WhatsApp as communication tools, and show how to use these tools to enhance interaction among instructors and students in order to increase their outcome. Secondly, future work should further investigate the learning outcomes, for example, using portfolio assessments. Lastly, text content delivered to the students and effective communication style should meet the needs of the student such as frequent sending messages in instructional method to assist in achieving higher engagement, better grades, and greater satisfaction.

\section{ACKNOWLEDGMENTS}

The author would like to express my gratitude to the Faculty of Information Technology, Thepsatri Rajahbat University, Thailand, which financially sponsored this research.

\section{REFERENCES}

Chaiprasurt, C. (2013). Enhancement of e-Learning Motivation through Interactive M-Learning. Faculty of Engineering. Thailand: Phatumthani, Asian Institute of Technology. Doctor of Philosophy (Publication No. IM13-02). 
Chaiprasurt, C., and Esichaikul, V. (2013). Enhancing Motivation in Online Courses with Mobile Communication Tool Support: A Comparative Study. International Review of Research in Open \& Distance Learning, 14(3): 377400.

Cocea, M., and Weibelzahl, S. (2006). Motivation-Included or Excluded From ELearning, in IADIS International Conference on Cognition and Exploratory Learning in Digital Age, CELDA 2006, Barcelona: Lisbon, pp. 435-437.

Dillenbourg P. (1999) What do yuo mean by collaborative leraning?, in Collaborative-learning: Cognitive and Computational Approaches, edited by P. Dillenbourg. Oxford: Elsevier, pp.1-19.

Jenny, W. A. N. G., Lin, C. F. C., Wei-Chieh, W. Y., and Emily, W. U. (2013). Meaningful engagement in Facebook learning environments: Merging social and academic lives. Turkish Online Journal of Distance Education, 14(1).

Keller, J. (1983). Motivational design of instruction, in Instructional design theories and models: An overview of their current status, edited by C.M. Reigeluth. Hillsdale, NJ: Erlbaum.

Keller, J. M. (1987). Development and use of the ARCS model of instructional design. Journal of Instructional Development, 10(3), 2-10.

Keller, J. M. (2008). First principles of motivation to learn and e3-learning. Distance Education. 29(2),175-185.

Keller, J. M. (2010). Motivational design for learning and performance: The ARCS model approach. New York: Springer.

Madge, C., Meek, J., Wellens, J., and Hooley, T. (2009). Facebook, social integration and informal learning at university: 'It is more for socialising and talking to friends about work than for actually doing work'. Learning, media and technology, 34(2), 141-155.

Mazer, J. P., Murphy, R. E., and Simonds, C. J. (2007). I'll see you on "Facebook": The effects of computer-mediated teacher self-disclosure on student motivation, affective learning, and classroom climate. Communication Education, 56(1), 1-17.

Miyake, N. (2007). Computer supported collaborative learning. The SAGE handbook of e-learning research, 248-265.

Patten, B., Arnedillo-Sanchez, I., and Tangney, B. (2006), Designing Collaborative, Constructionist and Contextual Applications for Handheld Devices, Computers \& Education, 46(3), 294-308. 
